\title{
Section 269 of the Internal Revenue Code and the Status of Postacquisition Losses
}

If a taxpayer acquires the assets or control of a corporation, any loss incurred after acquisition by either the acquirer or the acquired corporation will ordinarily be deductible from the current income of the other. However, such deductions have been denied recently by several courts. ${ }^{1}$ In support of this result courts have relied upon section 269 of the Internal Revenue Code, which provides that a deduction, unavailable to a taxpayer but for the acquisition of control or assets of a corporation, shall be disallowed if the acquisition was made with the "principal purpose" of avoiding income tax by securing the benefit of such deduction. ${ }^{2}$ These courts also relied upon case law which holds that a corporate group formed "without a business purpose" cannot file a consolidated tax return, ${ }^{3}$ as provided for in sections $1501-05$ of the Code. ${ }^{4}$ Since the acquisitions in these recent cases were effected by one corporation obtaining the control rather than all the assets of another

1 Luke v. Commissioner, 351 F.2d 568 (7th Cir. 1965); R.P. Collins \& Co. v. Commissioner, 303 F.2d 142 (1st Cir. 1962); Elko Realty Co., 29 T.C. 1012, affd per curiam, 260 F.2d 949 (3d Cir. 1958). This problem has been discussed in Adlman, Recent Cases Increasingly Extend Section 269 To Disallow Post-acquisition Operating Losses, 17 J. TAxation 282 (1962); Bean, Section 269 and Postacquisition Losses, 49 A.B.A.J. 907 (1963); Dominianni, Zanesuille Decision Places Much-Needed Brake on IRS' Misapplication of Section 269, 22 J. Taxation 88 (1965); Hagendorf, Zanesville Allows Tax Avoidance Through Use of Post-acquisition Operating Losses, $21 \mathrm{~J}$. TAXation 262 (1964).

2 INT. REv. CODE OF 1954, § 269(a):

In General. If-

(1) any person or persons acquire, or acquired on or after October 8, 1940, directly or indirectly, control of a corporation, or

(2) any corporation acquires, or acquired on or after October 8, 1940, directly or indirectly, property of another corporation, not controlled, directly or indirectly, immediately before such acquisition, by such acquiring corporation or its stockholders, the basis of which property, in the hands of the acquiring corporation, is determined by reference to the basis in the hands of the transferor corporation,

and the principal purpose for which such acquisition was made is evasion or avoidance of Federal income tax by securing the benefit of a deduction, credit, or other allowance which such person or corporation would not otherwise enjoy, then the Secretary or his delegate may disallow such deduction, credit, or other allowance. ...

3 J. D. \& A. B. Spreckels Co., 4 I B.T.A. 370 (1940).

4 Sections 1501-05 relate primarily to the filing of consolidated tax returns in which the losses of one or more corporations may under certain circumstances be deducted from the taxable income of others. The basic requirement for filing a consolidated return is that a group of corporations be affiliated in a parent-subsidiary relationship. INT. REV. CODE OF 1954, \& 1504(a). 
corporation, current deductions for the losses could have been obtained only by filing consolidated returns.

The stated objectives of the "principal purpose" and "business purpose" tests in the context of loss carryovers are "to prevent the tax liability from being reduced through the distortion or perversion effected through tax avoidance devices"5 and "to put an end promptly to any market for, or dealings in, interests in corporations or property which have as their objective the reduction through artifice of . . tax liability."6 These objectives seem to reflect the view that while losses are ascribed to corporate entities, their effects are borne by the human owners of those entities and that the mere purchase of an entity should not entitle the new owner to the tax benefit of a loss he never suffered. Thus, in analyzing a claimed deduction for losses associated with acquisitions, an important factor would appear to be the time at which the loss or expense was incurred. There is clearly an important difference between losses resulting from the postacquisition operation of the business and built-in losses incurred before acquisition but realized afterwards, such as result from selling an asset which at the time of acquisition had a market value below its tax basis. ${ }^{7}$ The identity of the individual owners before and after the acquisition would seem to be another important factor in analyzing claimed deductions. If the transfer of property or control is between members of the same economic unit, such as brother-sister groups in which two or more corporations are owned by the same individuals, the same persons suffer the impact of the loss whether incurred before or after acquisition. This is, of course, not true respecting transfers between economic units owned by different people.

The thesis of this comment is that the "principal purpose" test of section 269 and the "business purpose" test used by the courts in conjunction with sections 1501-05 should not be applied to deny deductions for postacquisition losses. Postacquisition losses are defined here as losses incurred by the acquired corporations after the statutory pre-

5 H.R. REP. No. 871, 78th Cong., 1st Sess. 49 (1943). The committee apparently intended that this language apply to the "business purpose" test of the Spreckels case, as well as to the objective of $\S 269$, since it cited with approval the result in that case.

6 H.R. REP. No. 871, 78th Cong., Ist Sess. 49 (1943). A typical artifice would be the acquisition by a profitable corporation of either a corporation with loss carryovers which can be applied against the new owner's profits or assets with a book value higher than liquidating or market value so that the purchaser will acquire a "built-in" loss if he can adopt the seller's cost basis of the asset.

7 A loss is "realized" when an event, such as the sale of an asset, takes place which prompts the taxpayer to recognize the loss in his accounts; a loss is "incurred" or suffered, however, when the actual permanent decline in value or loss of utility occurs. 
conditions for the filing of consolidated returns have been met or after merger, consolidation, or purchase of assets has been accomplished. Such losses should be deductible from the gross income of the acquiring corporations even if preacquisition losses-built-in losses and carryovers-are disallowed concurrently under these sections. The contrary result reached by the courts is a consequence both of the failure of Congress in drafting section 269 to express itself in terms of the relevant factors of timing and economic impact, and also of the resulting difficulty experienced by some courts in analyzing the factual situations before them. ${ }^{8}$

Although the leading case of $J . D$. \& $A$. B. Spreckels Co.9 did not involve postacquisition losses, the decision was couched in language which appeared to require generally that the acquisition of a corporation be for a business purpose for it to be includable in a group of "affiliated" corporations entitled to file consolidated returns. The Spreckels family owned the entire capital stock of both the taxpayer and the J. D. \& A. B. Spreckels Securities Company (Securities). Securities in turn owned all the outstanding stock of the Savage Tire Company (Tire). In 1927 and 1928 the taxpayer and Securities filed consolidated tax returns under the law which then included brother-sister corporations within the definition of "affiliation." The Revenue Act of 1928, however, disqualified brother-sister corporations from filing consolidated returns in subsequent years by restricting affiliation to corporations in a parent-subsidiary relationship, ${ }^{10}$ thus rendering the

8 Congressional comment on $\S 269$ (then INr. REv. CoDE of 1939, § 129) indicates that the objective of the section is to prevent the distortion of tax liability through "purchasing corporations with current, past, or prospective losses." H.R. REP. No. 871, 78th Cong., 1st Sess. 24 (1943). It is not clear, however, whether "prospective" refers to losses expected to be incurred after acquisition or merely to losses expected to be realized after acquisition even though the events causing the loss occur before acquisition (i.e., built-in losses).

Temple Square Mfg. Co., 36 T.C. 88 (1961), illustrates the courts' confusion. There the loss corporation discontinued its business before acquisition but did not actually liquidate its assets until after acquisition. While the capital loss was realized for tax purposes after acquisition, it was incurred as a practical matter the moment the business had only liquidation value. The court's language, however, was not limited to the particular factual situation: "Nothing in the language of the statutes indicates their application is to be confined to losses sustained [incurred or realized?] by the loss corporation in the years before acquisition. Once the principal puxpose of the acquisition is found, namely to evade or avoid tax, any deduction which would not otherwise be available, is rendered unallowable." 36 T.C. at 95.

941 B.T.A. 370 (1940).

10 Revenue Act of 1928, ch. 852, \& 142(c), 45 Stat. 791: "Definition of Affiliation [taxable year 1928]. For the purpose of this section two or more domestic corporations shall be deemed to be affiliated . . . if at least 95 per centum of the stock of two or more corporations is owned by the same interests ...." See generally Horwich, $A$ Comparative 
taxpayer unable to deduct any losses that might be incurred by Tire. In 1932 Tire contracted to sell its plant at a loss of $\$ 192,000$. To qualify under the new definition of affiliation and secure a deduction on a consolidated return for this capital loss, the taxpayer purchased the Tire stock from Securities a few hours prior to the consummation of the sale of the plant. The court determined that the taxpayer's "ownership of the stock of the Tire Co. did not serve a business purpose, as distinguished from a tax reducing purpose ... [and for that reason] held that the Tire Co. was not a member of the affiliated group."11

The court in Spreckels based its decision on an assessment of legislative intent:

It is apparent that the privilege to file a consolidated return was granted in order that the tax liability of a group of corporations which were combined for business purposes into one business unit might be based upon the true net income of the business unit. ... It is believed that they did not intend that the privilege be enjoyed in cases where that affiliation relied upon as the basis for the privilege to make a consolidated return is without a business purpose. ${ }^{12}$

But the statutory change in the definition of "affiliated group" for 1929 and subsequent years was not motivated by the belief that consolidation was justified only for corporations in the parent-subsidiary relationship and not for those in a brother-sister relation. Rather, the desire was to simplify the administration of the consolidation provisions by eliminating the difficulties surrounding the determination, necessary in brother-sister cases, of when "two or more corporations are owned by the same interests." 13 There is no indication that there was any desire to deny the privilege of consolidation once affiliation was again achieved by reorganization into parent and subsidiary, ${ }^{14}$ or to disallow

Study of Consolidated Returns and Other Approaches to the Multiple Corporations Problem, 20 TAX L. Rev. 529, 548-51 (1965).

1141 B.T.A. at 378.

$12 I d$. at 375 .

13 Revenue Act of 1928, ch. 852, § 142(c), 45 Stat. 791. The committee reports stated that the statutory changes were recommended "not upon the ground that consolidated returns were unsound, that additional revenues would be received by the elimination of the consolidated returns provision, but solely upon the ground that the administration of the law would be simplified." S. REP. No. 960, 70th Cong., 1st Sess. 13 (1928). See also H.R. REp. No. 2, 70th Cong., 1st Sess. 20 (1927); STAFF of Joint Committee on INTERnat Revenue Taxation, 70th Cong., Ist Sess., Report of the Joint Committee on Internal REvenue TAXation vol. 1, 63-66 (1927).

14 The general conclusion among tax counsel was that if consolidation was desired by the brother-sister groups they could simply alter the ownership structure by creating a parent-subsidiary relationship, thereby eliminating the administrative diffculties and 
any specific type of loss deduction. Given that brother-sister groups qualified for consolidation under the prior law together with the reason for the change in that law, it seems questionable to apply a "business purpose" test to determine the validity of an affiliation and thus the propriety of consolidated returns. Moreover, expressions of congressional intent indicate that the only precondition for affiliation and the resulting qualification for consolidated returns was a requirement of stock ownership sufficient to show a closeness of relationship such that no distortion of tax liability would result from treating them as one taxable entity. ${ }^{15}$

The promulgation of a "business purpose" test in Spreckels was unfortunate and misleading, even though the result reached in the case was sound. The court seemed to sense that the taxpayer, for the purpose of obtaining tax benefits, was attempting to take advantage of a built-in loss that as a corporate entity it did not suffer. However, the court could have reached the same result with less confusion if instead of employing the broad language of "business purpose" it had merely denied the deduction on the ground that the policy of administrative simplification underlying the 1928 change in the definition of "affiliated group" forbade the court to inquire whether the taxpayer would be entitled to the preacquisition loss of the acquired corporation by virtue of their being owned by the same interests. Rather than being a general test of the propriety of consolidated returns, "business purpose" should be no more than a test for determining whether preacquisition losses may be offset against the postacquisition income of an affiliated corporate group.

Although only preacquisition losses were involved in Spreckels, the "business purpose" test has been applied as a requirement in addition to those of section 269 to deny a deduction for postacquisition losses. In Elko Realty Co., ${ }^{16}$ Harold J. Fox, owner of nearly eighty per cent of the taxpayer's stock, acquired on January 1, 1951, all the outstanding stock of two corporations which owned and operated apartment projects financed with mortgages guaranteed by the Federal Housing Administration. Fox immediately transferred the stock to the taxpayer. When he purchased the stock of the two corporations for $\$ 16,000,{ }^{17}$ Fox apparently knew nothing of the actual financial performance of the

qualifying under the new provision. Patten, The Consolidated Return-1929 Model, 7 NAT'L INCOME TAX MAGazine 419, 420 (1929).

15 S. REP. No. 960, 70th Cong., 1st Sess. 13, 14 (1927).

1629 T.C. 1012, aff'd per curiam, 260 F.2d 949 (3d Cir. 1958).

17 There was only a nominal equity because of the very high debt to asset ratio. 
projects. ${ }^{18} \mathrm{He}$ knew only that the FHA project analyses indicated prospective profitable operations and that there was a high rate of occupancy in the projects. In fact, however, both projects had been operating unsuccessfully.

The taxpayer and the acquired corporations filed consolidated returns for the years 1951-1953 and deducted from the taxpayer's income the postacquisition operating losses of the projects. The Commissioner argued that the deductions should be disallowed under section 129 (now section 269 of the 1954 Code) because the principal purpose of the acquisition was to avoid federal income taxes and because the two new corporations were not affiliates for tax purposes since no business purpose was served by their acquisition. The Tax Court agreed with the Commissioner and disallowed the deduction because "the petitioner here has failed to show that a business purpose, as distinguished from a tax reducing purpose, was served by its acquisition....."19

In reaching this conclusion the court apparently neglected to distinguish preacquisition from postacquisition losses by ignoring completely the presence and character of two significant expense items, depreciation and mortgage interest. These, with the current operating expenses, accounted for the entire loss. While the depreciation expense may have represented in part the allocation of a loss incurred before acquisition, information presented in the opinion permits the conclusion that such allocated depreciation represented at most a small portion of the loss deduction claimed. ${ }^{20}$ Thus, almost the entire loss was

1829 T.C. at 1014.

19 Id. at 1026. That the business purpose doctrine has lost much of its vitality is demonstrated by Naeter Bros. Publishing Co., 42 T.C. 1 (1964), where the court went out of its way to find a business purpose. The business purpose of the acquisition, as approved by the court, was that affiliation would enable the group to submit consolidated financial statements to creditors and thus permit the presentation of total group assets and the elimination of intercompany indebtedness and other transactions. The court failed to point out, however, that these same financial statements could be prepared for the group even if they were not affliated for tax purposes. Consolidated financial statements merely combine the financial data from two or more entities for informational purposes, ownership of the entities being irrelevant.

20 For example, the court stated that for one project in 1951 the difference between rents and "certain of the actual expenses" (heat, light, water, taxes, maintenance, payroll, sewer) constituted "income" of $\$ 36,603$; the court also stated, however, that the net result of operations was a loss of $\$ 23,679$. The unexplained $\$ 60,282$ of expenses must have been composed primarily of mortgage interest and depreciation. In estimating mortgage interest, the original debt of $\$ 889,200$ incurred a few years earlier had probably been reduced to $\$ 800,000$ by 1951 . If we postulate an interest payment of $6 \%$ on this sum, the interest expense for 1951 would be $\$ 48,000$. Regarding depreciation, $2 \%$ of the original cost of $\$ 876,815$ would result in straight-line annual depreciation of approximately $\$ 17,500$. While some portion of this depreciation may properly be allocable to 
the result of postacquisition expenses. To disallow a deduction for losses actually incurred by the taxpayer for a reason other than extraordinary accounting difficulties in identifying the postacquisition loss would seem to be nothing more than a penalty imposed because the taxpayer could not show retrospectively that the acquisition was a wise business decision. As previously noted, the application of the business purpose test to deny consolidated returns is wholly unjustified; and while tax considerations may motivate a taxpayer to acquire a particular property, avoiding taxes could not have been Fox's primary purpose in incurring losses after the property had been acquired since under the then existing corporate income tax each dollar of loss created a tax saving of only fifty-two cents. ${ }^{21}$

It might be argued that while no one intends to incur out of pocket losses to secure a loss deduction it is possible that the principal purpose of the acquisition is the securing of other tax benefits and that all loss deductions related to the transaction should be disallowed to deter such conduct. This position was taken by the First Circuit in $R$. P. Collins \& Co. $v$. United States. ${ }^{22}$ The taxpayer purchased a controlling interest in Priscilla Worsted Mills with an option to buy the remaining outstanding stock. Priscilla had been operating at a loss and the taxpayer was able to purchase the stock at a price considerably less than the liquidation value of the assets which in turn was less than the tax basis of the assets. Priscilla continued to operate at a loss, and the taxpayer purchased the remaining outstanding stock and made plans to liquidate Priscilla's assets. Further operating losses were suffered by Priscilla during the two month period from the date of the exercise of the option until the date of liquidation when the built-in loss was realized. In a consolidated return for the period subsequent to the exercise of the option ${ }^{23}$ the taxpayer deducted the operating loss incurred after affiliation and the loss on the liquidation of assets. The taxpayer maintained that the purpose of the acquisition was to turn Priscilla into a profitable company and to liquidate only if that purpose could not be achieved.

The court of appeals upheld the district court's finding that the principal purpose of the acquisition was to secure to the purchaser the

a decline in value incurred before acquisition, the court would have to grant that the taxpayer was entitled to some deduction for depreciation. Furthermore, although no one would question the legitimacy of interest as a current expense, it appears to account for the major portion of operating expenses not considered by the court. 29 T.C. at 1016-17.

21 INT. Rev. CoDE of 1954, § 11.

22303 F.2d 142 (Ist Cir. 1962).

23 Section 141 of the 1939 Code (now INT. Rev. Code of 1954, \$\$ 1501-05) required 95\% stock ownership. 
deduction for the loss realized when the assets were sold. Thus, the deduction for the loss on the sale of the assets was disallowed because the decline in value took place before affiliation. The court rejected the taxpayer's contention that a deduction for postaffiliation operating expenses was justified since whatever his overall or principal purpose might have been there certainly was no intent or desire to incur operating losses after the acquisition, for the amount saved in taxes would be only fifty-two per cent of the amount of the loss. The court stated:

We find this argument unpersuasive because . . . it unrealistically attempts to segregate into isolated segments a course of conduct that is essentially unitary both in conception and in impact. Assuming . . . that the court could conclude that the "overall" purpose of the acquisition was to avoid taxes, ... then we believe that it must have been within the fair contemplation of the taxpayer that certain operating losses would necessarily be incurred before this ultimate purpose [liquidation] could be effectuated and, to that extent, the operating losses would be included as a necessary incident of the "overall purpose." ... [W] believe that all the losses which immediately precede this ultimate act [liquidation] are constituent elements of a course of conduct proscribed by Section 129. They are tarred by the same brush. ${ }^{24}$

Thus, the court refused to fragment the total transaction and consider independently the various deductions being sought. This was criticized in the dissenting opinion:

I believe the purpose of the statute is to frustrate a motive of acquiring built-in losses, to which taxpayer was a stranger, by striking down "such" losses [i.e. built-in losses]. . . . The court now strikes down actually incurred expenses, which would normally be allowed, because it finds that taxpayer wished to realize certain tax benefits . . . . ${ }^{25}$

Even assuming that the taxpayer's purpose was to secure the deduction for the built-in loss, in situations like that in Collins there are two possible views of the taxpayer's intent in acquiring a corporation which has suffered losses in the past and will continue to incur operating losses for at least some time after acquisition. One might conclude that the taxpayer, instead of liquidating Priscilla immediately after acquisition, decided to operate at a loss for a few months before liquidating in the hope that the Commissioner might be misled into thinking that the 
real intent was to rehabilitate Priscilla and that liquidation was decided upon only after original hopes had proved unrealistic. In this view the postacquisition operating losses were a device to hide the taxpayer's principal purpose, which was to obtain the tax benefits of a loss carryover or a built-in loss. One might argue that a deduction for these operating losses should be denied because it would provide additional deterrence to such attempted violations of section 269 and because these expenditures are socially wasteful since they serve no economic purpose. As indicated in Collins and in the recent case of Luke v. Commissioner, ${ }^{26}$ such losses can be disallowed by reading section 269 to apply even to losses incurred after acquisition. This approach, however, has the undesirable effect of confusing the status of postacquisition losses generally by subjecting them all to the force of section 269 whether or not they were accompanied by built-in losses. To avoid this confusion the courts could have explained clearly and candidly their reasons for disallowance or, better yet, might have fragmented the total transaction so as to consider the deductibility of those postacquisition losses independently of section 269 .

The second interpretation of Collins is that, even assuming an acquisition for the purpose of securing the benefit of a built-in loss, a company may reasonably continue to operate in the face of anticipated operating losses when it believes that those losses will be less than the losses which would be incurred had operations ceased. Under this view it might be argued that operating losses incurred between affiliation and liquidation should not be offset against current income, but should instead be treated as expenses in the computation of gain or loss on the sale of assets. However, this does not explain the Collins court's position since apparently it would have disallowed the deduction in any form. But since a deduction for these operating losses would not appear to violate any policy objective of section 269 and since built-in losses can be distinguished from postacquisition operating expenses, it would seem that only an extreme policy of deterring violations of section 269 would justify the court's tar brush technique. Under either characterization of the facts in Collins it is important to recognize that whatever the taxpayer's principal purpose may have been in making the acquisition, it does not seek to incur postacquisition losses for the purpose of obtaining a deduction for those losses.

The reasoning in Elko and Collins does not explain the tax treatment of postacquisition losses in a case like Zanesville Investment Co. $v$. Commissioner ${ }^{27}$ where, as in Spreckels, the preacquisition relation- 
ship was that of brother-sister corporations. The acquisition of the stock of one by the other from the common owners represents a change only in the legal ownership and not in the economic interests of the owners. Hence, unlike the transfers between unrelated entities in Elko and Collins, it is quite rational for a brother to acquire a sister corporation anticipating future operating losses since the common owners would have incurred the losses even without the acquisition. ${ }^{28}$ In Zanesville Earl Jones was the sole stockholder in the Muskingum Coal Company and in the taxpayer corporation. For several years Muskingum had suffered substantial operating losses. In 1955 it was attempting to return to profitable operation by investing heavily in modern equipment, but Jones anticipated that losses would continue in the near future. Hence, in that year he transferred all his Muskingum stock to the taxpayer with the purpose of deducting the anticipated losses on consolidated returns. Muskingum continued to operate at a loss until 1956 when it sold its assets at a loss of $\$ 480,000^{28}$ and filed a petition in bankruptcy. The Tax Court decided that the postacquisi- tion losses, both operating and capital, should be disallowed under section 269 and under the affiliation principle said to have been laid down in Spreckels. ${ }^{30}$ The Sixth Circuit reversed and allowed a deduction for postacquisition losses.

The Sixth Circuit assumed that section 269 was applicable to acquisitions among members of the same economic unit but held that neither section 269 nor the Spreckels doctrine applies to postacquisition losses. ${ }^{31}$ Although the conclusion appears sound, the court did not

28 The basic difference in motivation between an acquisition among related entities and an acquisition among unrelated entities can be perceived in the following example: Profitable corporation $A$ seeks to acquire corporation $B$, a company without a loss carryover or a built-in loss. $A$ believes that $B$ ultimately will be very profitable but anticipates that $B$ will suffer operating losses for six to ten years before profits will be achieved. If $B$ files a separate corporate return it may lose the tax benefit of the anticipated losses because of the time limitations on carryovers and carrybacks, but if $A$ and $B$ file consolidated returns the group will obtain a deduction for all anticipated losses. If before acquisition $A$ and $B$ are not related by common ownership, it is clear that the acquisition will not be tax motivated but the decision to file consolidated returns will be. However, if $A$ and $B$ are related by common ownership before acquisition, the acquisition will be tax motivated since the sole objective is to file consolidated returns.

29 The government did not contend that any part of this capital loss was incurred prior to acquisition.

3038 T.C. 406, 414 (1962), rev'd, 335 F.2d 507 (6th Cir. 1964).

31 The court relied on the following reasons to justify its result:

1) Individuals, partnerships, and corporations are permitted to offset losses of one business against profits of another business.

2) Regulation 1.1502-31(b) (1965) indicates that only preaffiliation losses (and not postaffiliation losses) may not be utilized against postaffiliation income.

3) Rev. Rul. 63-40, 1963-1 CuM. BuL. 46, states that when there is no change in 
provide a rationale for a critical examination of the precedents. Without the necessary analysis it cited Spreckels for the proposition that preaffiliation losses cannot be utilized by the new group, rather than for the proposition for which it is usually cited, that consolidated returns will not be allowed if affiliation is without a business purpose. Elko Realty was distinguished by ignoring the effect of mortgage interest on postacquisition reported losses and insisting that the losses represented depreciation of assets on their preacquisition bases and were thus an allocation of preacquisition losses. The court distinguished Collins as standing merely for the "tarred by the same brush" proposition employed in that case and assumed that "the post-affiliation operating loss [would have been allowed] . . . if it stood by itself." 32 Thus, the court failed to clarify the apparent inconsistency between its decision and Collins as to the general applicability of section 269 to postacquisition losses.

The result in Zanesville appears to be correct. First, it is consistent with the idea that the policy of section 269 may be violated by the taxpayer's attempt to take advantage of the losses incurred by another but not by his attempt to plan and organize his financial affairs so as to minimize his tax liability. This view would permit the taxpayer to plan for postacquisition events but not to alter the tax treatment of preacquisition events. In the preacquisition period the taxpayer chose to employ the brother-sister relationship and to obtain the advantages of filing a separate return ${ }^{33}$ for each corporation. For the postacquisition period the taxpayer chose to forego these advantages for the advantages of consolidated returns, but by effecting a parent-subsidiary relationship it is not entitled to the tax benefit of the acquired corporation's loss carryovers or built-in losses since this would treat the taxpayer as if the advantages of consolidated returns also applied to the preacquisition period. Second, the court provides much needed judicial recognition that section 269 does not operate to disallow postacquisition losses. Finally, the result encourages investment in, and thereby

the control group $\$ 269$ did not apply to the acquisition of a profitable business by a loss corporation which had discontinued the losing business.

4) Section 382 of the Code permits the deduction of preacquisition losses against income of other businesses when "either there has not been a change in the control group (as defined therein) or there has not been a substantial change in the trade or business conducted before the change in control." 335 F.2d 507, 512 (6th Cir. 1964).

5) S. REP. No. 960, 70th Cong., 1st Sess. 13-15 (1927); S. REP. No. 617, 65th Cong., 3d Sess. 8.9 (1919).

32335 F.2d 507, 511 (6th Cir. 1964).

33 For example, on separate returns each member of the group has a $\$ 25,000$ surtax exemption whereas on a consolidated return the entire affiliated group has only one $\$ 25,000$ exemption; also, prior to 1964 the surtax rate was ordinarily increased by $2 \%$ if consolidated returns were filed. 
the rehabilitation of, unprofitable corporations by allowing a current deduction from the income of affiliated corporations for the postacquisition losses of the acquired corporation. ${ }^{34}$

The situations and cases heretofore discussed have been concerned with the treatment of losses incurred after the acquisition by a profitable entity of an unprofitable corporation. It has been argued that in this situation the acquisition of a corporation from a stranger can be explained rationally only by business and not tax reasons since the loss of a dollar creates less than a dollar in tax savings. However, when both the acquiring and acquired corporations were owned by the same interests, tax motives may very realistically explain the acquisition since the postacquisition losses will be suffered by the owners in any event, but the motive is irrelevant when there is no attempt to alter the tax treatment of preacquisition events. A distinct situation arises, however, when it is the acquiring corporation which anticipates incurring losses in the future. ${ }^{35}$ If the acquiring corporation has reason to believe that anticipated future profits justify incurring short-run losses rather than discontinuing operations, tax considerations will be sufficient to motivate the acquisition of a profitable corporation even when the acquired corporation is purchased from strangers. This would permit the losses to be deducted currently from the income of the profitable corporation.

If there is no significant change in the ownership of the loss corporation during or after the time the losses are incurred, an application of the policies discussed thus far suggests that the deduction of losses should be allowed even though the acquisition was tax motivated. Because the taxpayer itself incurred these losses, its tax liability would not be distorted. In addition, it cannot be argued that this would involve any trading in loss corporations. However, it might encourage trading in profitable corporations if loss corporations were willing to pay more than the market price for the profitable corporation because of the necessity to have profits available immediately against which loss carryovers could be offset to avoid the time limitation on carryovers. ${ }^{36}$ Despite this possibility, the actions of the Internal Revenue Service support the view that postacquisition losses in such situations should be allowed, ${ }^{37}$ and in Revenue Ruling $63-40^{38}$ the IRS states that deduc-

3478 HaRv. L. REv. 1479 (1965).

35 See generally Speiller, Acquisitions by Loss Corporations of Profitable Businesses, 40 TAXES 22 (1962).

36 INT. Rev. CODE OF 1954, § 172(b)(1)(B). .

37 In Kolker Bros. Inc., 35 T.C. 299 (1960), a taxpayer suffering operating losses decided to acquire the assets of a business that it thought could be operated profitably. The new business activity was profitable, but the original activity continued to lose 
tions for preacquisition and postacquisition losses will be allowed to a loss corporation that acquired the assets of a profitable business and discontinued the money-losing activity provided there is no significant change in the ownership of the loss corporation. If the loss corporation decides to continue the losing activity in the belief that it will ultimately be profitable, it is difficult to see why a deduction should not still be allowed. ${ }^{30}$

In summary, whether the acquisition of property or control took place between different economic units or members of the same unit, the deductibility of losses incurred after acquisition should not depend on the motives for acquisition or the fact that losses incurred prior to acquisition were disallowed. Section 269 and the Spreckels doctrine should be limited to deny deductions only for preacquisition losses.

money and was liquidated. The Commissioner did not contend that its postacquisition losses should not be offset against the income from the profitable corporation.

38 1963-1 Gum. BuLl. 46.

39 It is possible that permitting deductions might be used to subsidize indefinitely an unprofitable businęss for noneconomic reasons such as social prestige and leisure time activity. 